\title{
Marine vertebrate remains from the Toarcian-Aalenian succession of southern Beaujolais, Rhône, France
}

\author{
PEGGY VINCENT*†, JEREMY E. MARTIN $\ddagger$, VALENTIN FISCHER $₫$, GUILLAUME \\ SUAN\|\#, BOUZIANE KHALLOUFI** ${ }^{*} \dagger$, BAPTISTE SUCHÉRAS-MARX $\ddagger \dagger$, ALEX \\ LÉNA\#, KÉVIN JANNEAU§ §, BRUNO ROUSSELLEq \& LOUIS RULLEAU\|\| \\ * Staatliches Museum für Naturkunde, Rosenstein 1, D-70191 Stuttgart, Germany \\ $\ddagger$ School of Earth Sciences, University of Bristol, Wills Memorial building, Queen’s Road, Bristol BS8 1RJ, UK \\ §alaeontology department, Royal Belgian Institute of Natural Sciences, Brussels, Belgium \\ ๆDépartement de Géologie, Université de Liège, Liège, Belgium \\ |Institute of Geosciences, Goethe University Frankfurt, Altenhöferallee 1, D-60438, Frankfurt am Main, Germany \\ \#UMR CNRS 5276 LGL-TPE, Université Claude Bernard Lyon 1 - Ecole Normale Supérieure Lyon, Campus de la \\ Doua, Bâtiment Géode, 69622 Villeurbanne Cedex, France \\ ** Centre de recherche sur la paléobiodiversité et les paléoenvironnements, UMR 7207, Département Histoire de la \\ Terre, Muséum national d'Histoire naturelle, Paris, France \\ $\dagger \dagger$ Departamento de Zoologia, Instituto de Biologia, Universidade do Estado do Rio de Janeiro, Rio de Janeiro, Brazil \\ † Department of Earth Sciences, Palaeobiology Programme, Uppsala University, Villavägen 16, SE-752 36 Uppsala, \\ Sweden \\ $\S \S$ Jardin des sciences, Université de Strasbourg, F-67000 Strasbourg, France \\ ๆฯEspace Pierres Folles, 116 chemin du Pinay, 69380 St-Jean-des-Vignes, France \\ || || 169, chemin de l'Herbetan, 69380 Chasselay, France
}

(Received 19 January 2012; accepted 30 October 2012)

\begin{abstract}
A previously undocumented marine vertebrate fauna comprising ichthyosaur, plesiosaur, marine crocodilian and fish remains from the Toarcian-Aalenian succession at Lafarge quarry, southern Beaujolais (Rhône, France) is described on the basis of both historical collections and new discoveries. The taxonomic composition of the Lafarge quarry marine vertebrate assemblage highlights its cosmopolitan nature and strong relationships with taxa known from elsewhere in Europe. Several groups are recorded for the first time in the Toarcian-Aalenian succession of France, implying new palaeobiogeographic interpretations and prompting discussion of marine amniote diversity during this interval.
\end{abstract}

Keywords: diversity, France, Jurassic, marine vertebrates.

\section{Introduction}

The Early Jurassic period is marked by an episode of biological crisis that occurs towards the PliensbachianToarcian boundary and continues into the early Toarcian (Little \& Benton, 1995; Harries \& Little, 1999; Macchioni \& Cecca, 2002; Wignall, Newton \& Little, 2005; Suan et al. 2008; Caswell, Coe \& Cohen, 2009). This biotic crisis seems to have ensued from marked temperature changes and broadly coeval onset of seawater oxygen deficiency (Baudin, Herbin \& Vandenbroucke, 1990; Harries \& Little, 1999; Wignall, Newton \& Little, 2005; Caswell, Coe \& Cohen, 2009; Gómez \& Goy, 2011), termed the Toarcian Oceanic Anoxic Event (T-OAE; Jenkyns, 1988). The impact of this crisis on the marine vertebrates, however, remains poorly understood (Benton, 1993).

Early Jurassic marine vertebrate history is particularly important, as this time witnessed the radiations of three major groups of successful marine amniotes, namely the thalattosuchian crocodiles, the neoichthyosaurian ichthyosaurs and the plesiosaurs (Benton,

$\nmid$ †uthor for correspondence: pvincent@mnhn.fr 1990a, b; Benson, Evans \& Druckenmiller, 2012). Particularly diversified and abundant remains of marine amniotes have been recorded in Toarcian strata of western Europe, making the assemblages of this age the most diversified and well known of the Early Jurassic (e.g. Westphal, 1962; Benton \& Taylor, 1984; Pierce \& Benton, 2006; Delfino \& Dal Sasso, 2006; Großmann, 2007; Bardet et al. 2008a; Bardet, Pereda Suberbiola \& Ruiz-Omeñaca, 2008b; Maisch, 2008; Vincent \& Smith, 2009; Vincent, 2011). In contrast, estimates of marine amniote diversity (e.g. Benson et al. 2010; Thorne, Ruta \& Benton, 2011) infer a minimum at the beginning of the Middle Jurassic (Aalenian-Bajocian), although poor sampling from strata of this age (Bardet, 1994) implies artificial heterogeneity. Therefore, it is still unclear whether these diversity patterns reflect environmentally driven faunal turnover or simply result from a sampling bias.

In this context, the abundant invertebrate and vertebrate specimens spanning the whole Toarcian and part of the Aalenian stage from the Beaujolais area in France might provide clues about the diversity alteration through this critical interval. Indeed, thirty years of excavations in the Lafarge cement quarry in southern 


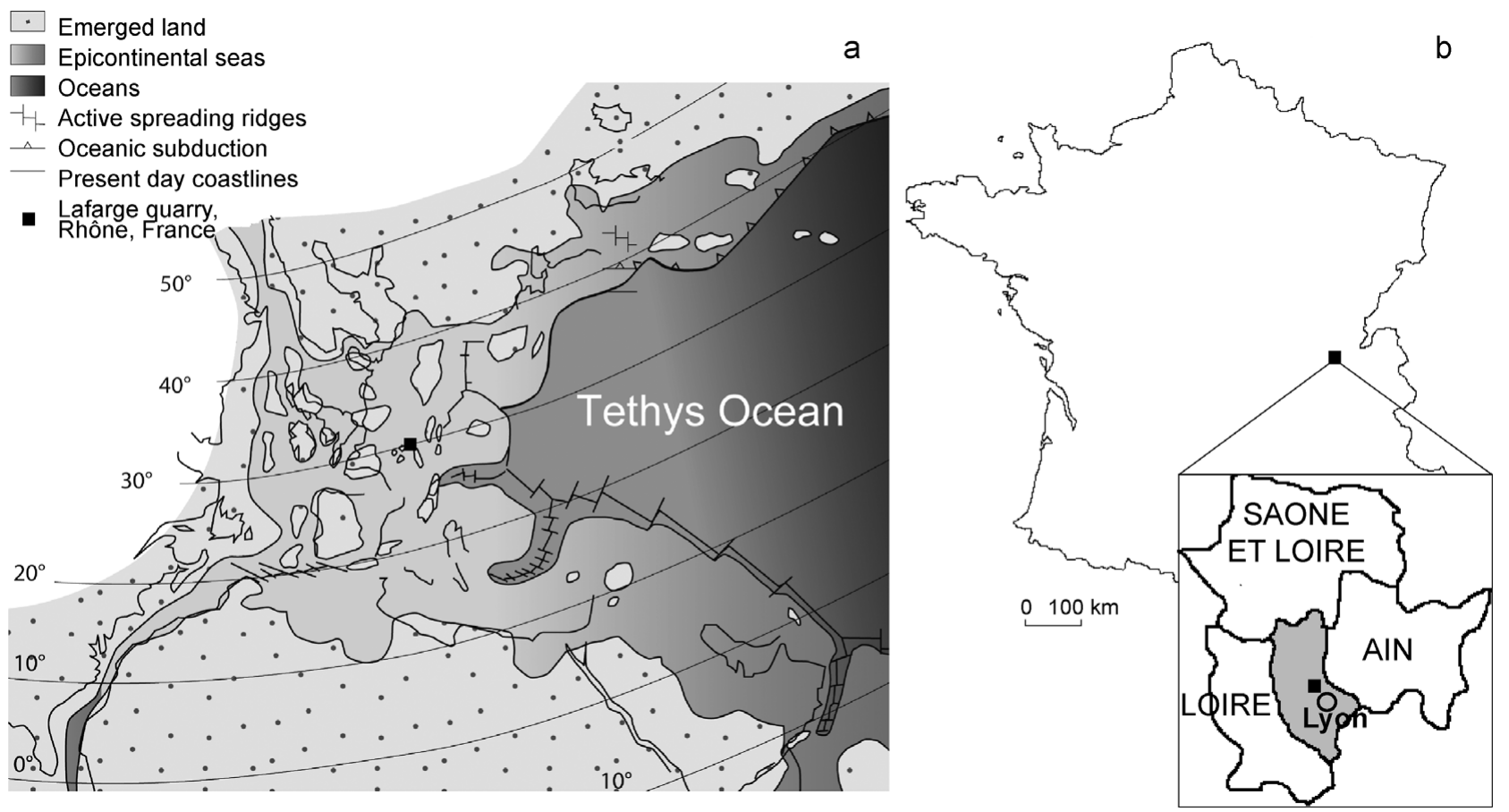

Figure 1. Location of the Toarcian-Aalenian succession of the Lafarge quarry. (a) Palaeogeography of the western margin of the Tethys Ocean during the Early Jurassic (from Suan et al. 2008) showing the position of the Lafarge quarry. (b) Regional position of the Lafarge quarry.

Beaujolais, France, as well as scientific exploration, have provided a wealth of new palaeontological and biostratigraphical data from the Lower and Middle Jurassic strata at this locality. Although the invertebrate fauna of the succession has been extensively studied (Elmi \& Rulleau, 1991, 1993; Rulleau, 2006), the vertebrate associations and their occurrence throughout the succession have not been described. This paper relies on collected samples now stored at the nearby museum of Espace Pierres Folles in Saint-Jean-desVignes, Beaujolais and from recent field investigations of the Lafarge quarry site. An account and a brief description of the vertebrate fauna is presented for this succession: the presence of Chondrichthyes, Actinopterygii, Ichthyosauria, Plesiosauria and marine crocodilians is attested by cranial and postcranial elements, the first two taxa being newly reported at this locality, thus implying a potential for further recovery of complete material. This report adds a substantial comparative basis to the knowledge of contemporaneous marine vertebrates from Europe such as Holzmaden (Germany; Urlichs, Wild \& Ziegler, 1994) and Yorkshire (England; Benton \& Taylor, 1984), and helps to constrain the evolution of vertebrate fauna across the Early-Middle Jurassic transition.

Institutional abbreviations. GLAHM, - University of Glasgow, Hunterian Museum, Glasgow, Scotland, UK; MAMSPL - Musée des Amis de la Mine, SaintPierre-la-Palud, Rhône, France; MHNL - Muséum d'Histoire Naturelle de Lyon, Lyon, France; PF Espace Pierres Folles, Saint-Jean-des-Vignes, Rhône, France.

\section{Geological setting and lithostratigraphy}

The Lafarge quarry, near the villages of Saint-Jeandes-Vignes, Belmont and Charnay (Beaujolais, Rhône, SE France), exposes a succession of fully marine strata of Toarcian to Bajocian age that were deposited at relatively shallow depths near the easternmost reach of the Massif Central (Fig. 1). The lithostratigraphy and ammonite biostratigraphy of the section were described by Elmi \& Rulleau (1991, 1993). Excavations undertaken in 2009 and 2010 in the southern part of the quarry allowed new detailed observations and sampling of the Toarcian to lowermost Aalenian sequence, including the lower Toarcian interval, which is otherwise poorly represented in the quarry (Rulleau, 1997). The lower Toarcian is mainly represented by partly dolomitized, massive and yellowish argillaceous limestone beds interbedded with weathered yellow plastic clays ('Calcaires à Ammonitella'; Elmi \& Rulleau, 1991). The first beds yielded specimens of Dactylioceras (Orthodactylites) diagnostic of the tenuicostatum zone, while overlying beds yielded abundant belemnite rostra and several ammonites diagnostic of the serpentinum ammonite zone (Fig. 2). This carbonate-rich interval is overlain by an interval $\sim 2.5 \mathrm{~m}$ thick (from 2.7 to 5.3 m; 'Marnes inférieures'; Elmi \& Rulleau, 1991) of dark grey, finely laminated calcareous marl (yellow and structureless when deeply weathered) presenting several millimetre-thick pyritic beds rich in vertebrate debris and belemnite rostra towards its base and equivalent to the classical 'Schistes Cartons' of the Paris Basin. The middle Toarcian sequence (bifrons zone to 


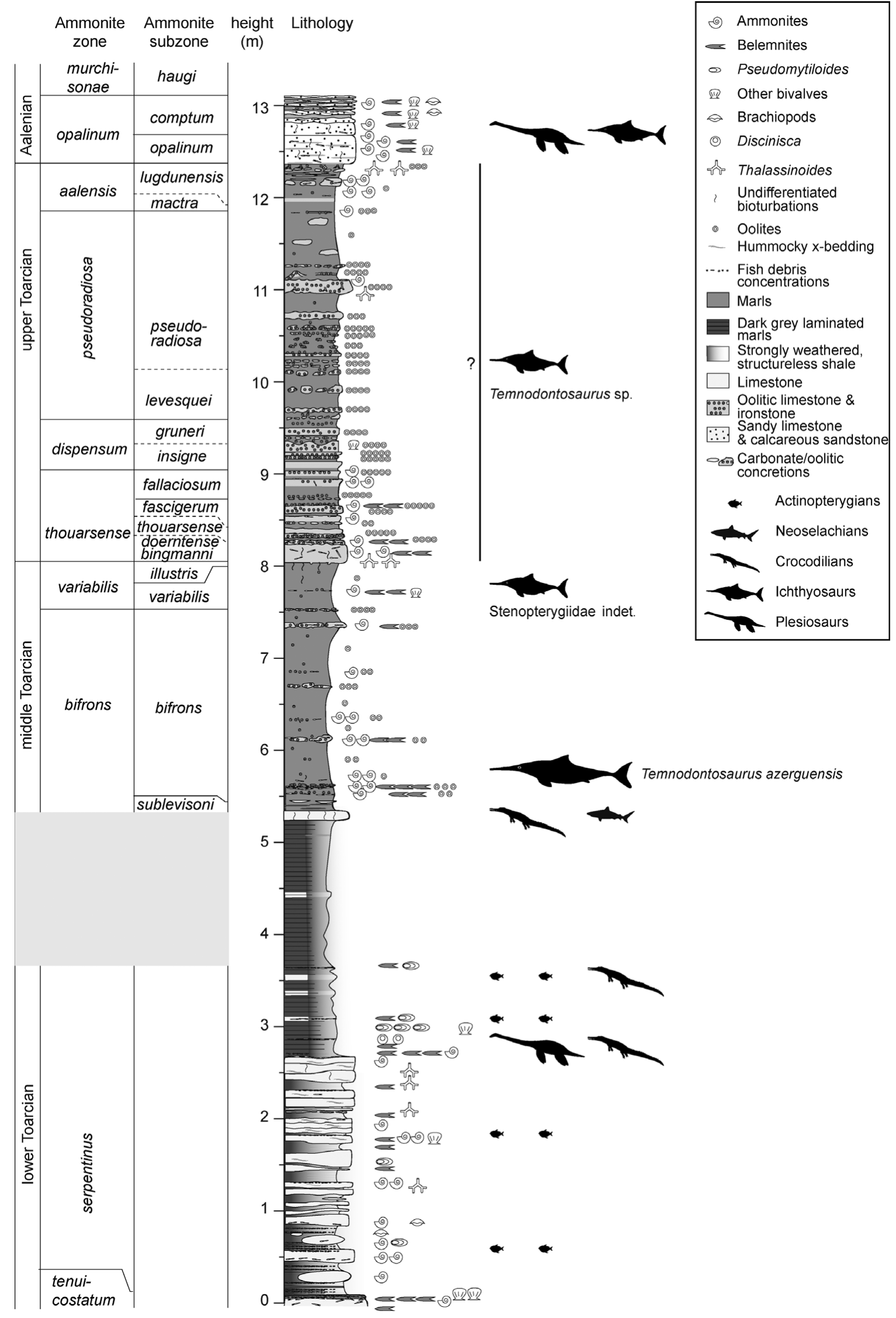

Figure 2. Stratigraphic $\log$ of the Toarcian section and base of the Aalenian at Lafarge quarry, Rhône, France together with the distribution of discovered vertebrates. 
variabilis zone) is represented by an $\sim 2.5 \mathrm{~m}$ interval of ammonite- and belemnite-rich purplish bioturbated marls ('Marnes médianes'; Elmi \& Rulleau, 1991) with a few dispersed phosphatic ooliths and interrupted by thin and discontinuous oolithic limestone beds. The upper Toarcian sequence, from 8 to $12.4 \mathrm{~m}$, ('Marnes supérieures'; Elmi \& Rulleau, 1991) consists of purplish to greenish grey bioturbated marls (deep red when weathered) that yielded abundant belemnites, bivalves and ammonites. Several massive, orange to reddish oolithic limestone beds occur towards the base, the lowermost of which being more prominent and especially rich in ammonites and belemnites ('Banc à Haugia et à Grammoceras'; Elmi \& Rulleau, 1991). An intensively bioturbated, massive and sandy yellowish bioclastic limestone bed at $12.4 \mathrm{~m}$ ('Dalle à Leioceras'; Elmi \& Rulleau, 1991) marks the base of the more calcareous and coarser sequence of the lower Aalenian (opalinum ammonite zone), which consists mainly of yellowish to pinkish sandy calcarenite and calcareous sandstone beds (Fig. 2).

\section{Survey of the marine vertebrate material}

\section{3.a. Chondrichthyes}

Chondrichthyian fossils occur in the middle Toarcian (MHNL 20103017), bifrons zone (PF Toa 623), variabilis zone? (PF Aal 323), through to the lower Aalenian (PF Aal 32 and PF Aal 312). Diagnostic elements include: two hybodontiform spines (PF Aal 321, Fig. 3a, b and PF Aal 323, Fig. 3c), a lateral tooth of Asteracanthus sp. (PF Aal 312; Fig. 3d), one Hybodus tooth (MHNL 20103017; Fig. 3e, f) and one neoselachian tooth (PF Toa 623; Fig. 3g).

PF Aal 323 (22 cm in length) is a nearly complete spine missing its tip. It is gently curved posteriorly and laterally flattened being taller $(3 \mathrm{~cm})$ than wide, the width decreasing from the base to the tip of the spine. Laterally, the spine is flanked by about 14 longitudinal ribs in the mid-region that seem to anastomose anteriorly to about 10 ribs. The dorsal and lateral areas of the base of the spine are devoid of ornamentation and correspond to the insertion area of the spine in the body of the shark. Although the presence of denticles on the ventral surface of the spine of PF Aal 321 cannot be assessed here due to the area being covered with sediment, the fin spine is overall very similar to that seen in Hybodus, Asteracanthus, Lissodus and Acrodus (Maisey, 1978); the presently described specimen could represent any of those taxa.

PF Aal 312 is a low crown plate-like tooth measuring $2.3 \mathrm{~cm}$ long and $1.1 \mathrm{~cm}$ wide. The root is not visible. In occlusal view, the crushing crown is nearly rectangular (slightly asymmetric) presenting a fine set of reticulations, a characteristic of a lateral tooth of Asteracanthus sp. (Rees, 2008). An occlusal crest is absent.

MHNL 20103017 is a large tooth crown belonging to the cladodont morphotype. It has a longitudinal length of $2.5 \mathrm{~cm}$ and is $0.6 \mathrm{~cm}$ wide at the level of the central cusp. The crown is slightly asymmetric. It possesses one main central abraded cusp, which is flanked by one cusp then one cusplet mesially, and by one cusp then by two cusplets distally. Lingually, vertical ridges originate above the base of the crown, which is smooth and flattened. Labially, vertical ridges descend to the base of the crown. Here, the surface is irregular and ornamented with nodes. Labially and lingually, the ridges do not anastomose and meet near the apex of the cusps and cusplets. Medial and distal cusp apices are smooth. In occlusal view, a single longitudinal crest extends for the mesio-distal length of the crown. This tooth is attributed to Hybodus sp. because the crown is mesio-distally long and relatively low, by the presence of a large central cusp flanked by smaller cusplets, the presence of nodes on the labial side of the crown and the presence of an occlusal ridge extending for the entire mesio-distal length.

$\mathrm{PF}$ Toa 623 is a minute tooth (crown height $=3 \mathrm{~mm}$ ) attached to the umbilicus of Hildoceras bifrons, within a shallow depression on the shell. The crown is taller than wide, triangular with a pointed apex and slightly curved labially. The root is broken. The shape of the crown indicates for the first time the presence of a neoselachian in the bifrons zone of the Lafarge quarry. The association of this tooth with an ammonite might indicate a trophic interaction, a case similar, though less obvious than a recently reported close association between hybodont teeth and ammonite (Vullo, 2011).

\section{3.b. Actinopterygii}

Actinopterygian remains from the Lafarge Quarry occur in the lower Toarcian serpentinus zone (MHNL 2013062, MHNL 2013064, PF Toa 472), through to the bifrons subzone of the middle Toarcian (MHNL 20103063). Diagnostic elements include an incomplete skull with parts of pectoral girdle and fins (MHNL 2013062; Fig. 3h), an isolated ganoid scale (MHNL 20103063; Fig. 3i), an ornamented bone fragment (MHNL 20103064; Fig. 3j) and incomplete posterior postcranial portions with pelvic and anal fins (PF Toa 472 and one unnumbered fragment; Fig. 3k-1).

MHNL 2013062 preserves a massive dentary showing a well-developed coronoid process located anteriorly, a quadrate-mandibular articulation placed below the posterior half of orbit, and a preopercle possessing two well-defined limbs forming a slightly obtuse angle; the vertical one is more elongated than the horizontal one (Fig. 3h). The preopercular sensory canal shows about eight or nine unbranched diverticula in the horizontal limb of the bone and two others in the vertical limb. This specimen can probably be referred to the genus Leptolepis on the basis of the general proportions of the skull, the very anterior position of the coronoid process and the shape of the preopercle. According to the diagnoses of Nybelin (1962, 1974), a preopercular sensory canal with a small number of unbranched diverticula is diagnostic of L. normandica, 


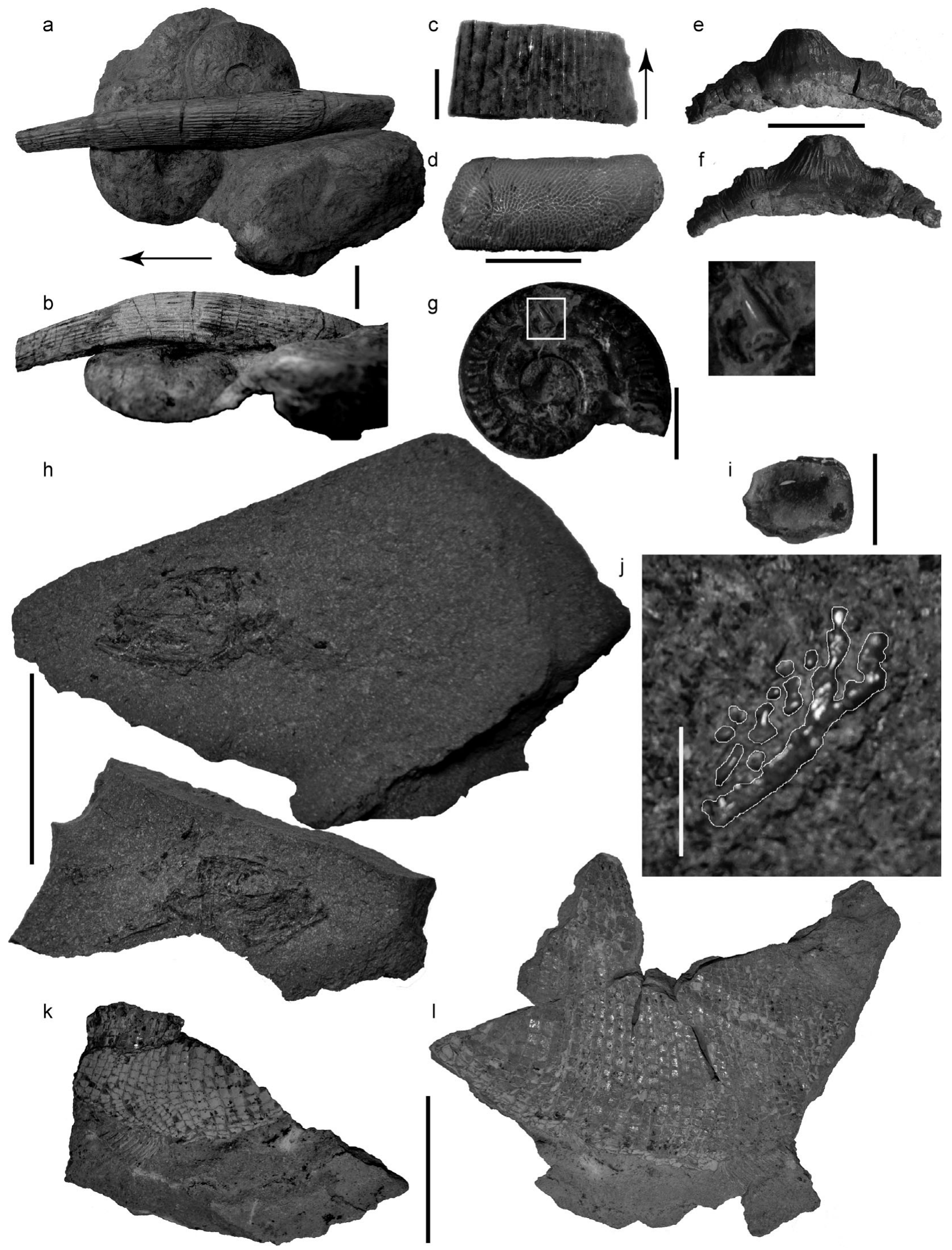

Figure 3. Chondrichthyan and actinopterygian remains from the Toarcian-Aalenian of Beaujolais, France. (a, b) Hybodontiform fin spine (PF Aal 321). (c) Fragment of hybodontiform fin spine (PF Aal 323). The arrows point toward the apex of the spines. (d) Low crown plate-like tooth of Asteracanthus sp. (PF Aal 312). (e, f) Hybodus tooth (MHNL 20103017). (g) Neoselachian tooth on ammonite (PF Toa 623) with enlargement of outlined area. (h) Skull of Leptolepis sp. (MHNL 20103062). (i) Ganoid scale (MHNL 20103063). (j) Dapedium-like cranial bone ornamentation (MHNL 20103064) outlined in white. (k) Postcranial part of ?Dapedium sp. (PF Toa 472). (1) Postcranial part of ?Dapedium sp.(unnumbered). Scale bars represent: (a, d, e, f, g, i, j) $1 \mathrm{~cm}$; (c) $0.2 \mathrm{~cm}$; (h) $3 \mathrm{~cm}$; (k, 1) $5 \mathrm{~cm}$. 
but better-preserved material is necessary to assert this specific determination.

MHNL 20103063 consists of a square-shaped scale without ornamentation and with surface and edges smoothed by erosion, possibly referable to Lepidotes or Dapedium (Fig. 3i). MHNL 20103064 consists of a ganoid specimen showing a rugae-like superficial bone ornamentation that is usually found on cranial bones of Dapedium or Tetragonolepis (Wenz, 1967; Thies, 1991). The incomplete posterior postcranial portions (PF Toa 472 and one unnumbered fragment; Fig. $3 \mathrm{k}, 1)$ preserve fulcra that are present anteriorly to the insertion of the anal fin. Anal fin rays are thick and spaced. The body is covered by ganoid scales of different shape and size; the ones located close to the anal fin are the smallest. Scales located in the ventral or posterior part of the specimen are square-shaped or longer than high; other scales are higher than long. Some dorsal and ventral scale edges are wave-shaped. The shape of the ventral profile corresponds to a deepbodied fish. Orientation and shape of scales suggest affinities with Dapedium (Agassiz, 1833-1844; Wenz, 1967).

\section{3.c. Ichthyosauria}

Ichthyosaurian remains occur in the Toarcian (PF Toa 514; PF Toa 467), serpentinum zone (MHNL 20103011), bifrons zone (MAMSPL uncatalogued), variabilis zone (MHNL 20103016), upper Toarcian (PF Toa 485), through to the lower Aalenian (PF Aal 308 and PF Aal 309). Diagnostic elements include: an almost complete skeleton (MAMSPL uncatalogued) of Temnodontosaurus azerguensis Martin et al. 2012; non-diagnostic cranial material (PF Toa 467); partial cranial material of Temnodontosaurus sp. (PF Toa 485); partial postcranial material of Thunnosauria indet. (PF Toa 514); partial postcranial material of nonthunnosaurian Neoichthyosauria (MHNL 20103011); partial postcranial material of Thunnosauria (MHNL 20103016); and partial cranial and postcranial material of Ichthyosauria indet. (PF Aal 309; PF Aal 308).

PF Toa 467 is a partial rostrum whose structure is clearly revealed in a transverse section (Fig. 4a). A deep and thin fossa praemaxillaris runs along the premaxilla. The nasals form a ridge-like convexity on either side of the dorsal surface and concealed beneath the overlapping premaxilla. The anterior part of the vomer is excluded from the palate by the premaxilla. The vomer contacts the lingual wall of the premaxilla and is buttressed ventrally by the palatal processes of the premaxilla. The lingual wall of the dentary is smaller than that of the premaxilla. Each dentary bears a shallow fossa dentalis. The splenial is curved and contacts the dentaries along a straight suture. The surangular is a very low and slender element. Its ventral part contacts the splenial. Tooth crowns are slender, pointed, and straight. The root is not bulbous.

PF Toa 485 is a pair of tooth-bearing bones here identified as the premaxillae (Fig. 4b). They surround a large and rounded internal cavity, the central canal. The premaxilla is thick and its lateral surface exhibits a thin and shallow fossa praemaxillaris. The dental grooves are large. The nasals are present in the central canal as two thin convex elements. The teeth are large, thick, and rounded in cross-section. The crown is textured by deep and widely spaced apicobasal ridges, which extend on to the slightly bulbous root. This specimen is tentatively referred to Temnodontosaurus sp. based on the tooth morphology: Temnodontosaurus is the only genus of Liassic ichthyosaur combining large teeth with bulbous roots and deep apicobasal ridges (Godefroit, 1993; McGowan, 1996; pers. obs.); deep apicobasal ridges are also found in some species of Ichthyosaurus and Suevoleviathan but these taxa lack the bulbous roots (Godefroit, 1996; Maisch, 2001; pers. obs.). The precise position of the bed that yielded this specimen is not recorded. However, the matrix surrounding the specimen exhibits a highly distinctive red colour that is absent in the Aalenian and lower and middle Toarcian strata of the study site, but commonly found towards the top of the Toarcian sequence (see Section 2). These observations indicate that the specimen almost certainly comes from the upper Toarcian, though further attribution to a given ammonite zone is as yet impossible.

PF Toa 514 consists of a series of 20 centra, including posterior dorsal and caudal elements (Fig. 4c). They were found in a block, having being displaced before burial. Diapophyses and parapophyses are separated and lie at the ventral half of centrum, a feature of thunnosaurian ichthyosaurs (Sander, 2000). The only thunnosaurian ichthyosaurs known from the European Toarcian record appear to be stenopterygiids (Stenopterygius + Hauffiopteryx), but this assignation is made by default. Accordingly, the material is assigned to Thunnosauria indet.

MHNL 20103011 is a large and elongated propodial lacking the proximal half (Fig. 4d). The trochanters are low and do not extend further than mid shaft. The shaft is moderately constricted and the distal extremity is flat and anteroposteriorly expanded. Two large and flat facets are present distally. The specimen can be referred to as non-thunnosaurian Neoichthyosauria (Leptonectidae, Temnodontosaurus, Suevoleviathan) despite its incompleteness. Indeed, the humeri of non-thunnosaurian neoichthyosaurs lack prominent trochanters (e.g. McGowan \& Motani, 2003). This is corroborated by the wide and flat distal end and the flat and elongated distal facets, which characterize the propodials of non-thunnosaurian neoichthyosaurians. Within this clade, the propodial closely resembles that of Temnodontosaurus (Godefroit, 1993; McGowan \& Motani, 2003).

MHNL 20103016 is an incomplete femur with a partially preserved distal end (Fig. 4e). The femur is short and possesses a poorly developed dorsal trochanter and a prominent ventral ridge, both of which vanish before mid-shaft. The anterior surface is flat and triangular whereas the posterior surface is blade-like, as in thunnosaurian ichthyosaurs (e.g. Ichthyosaurus: 

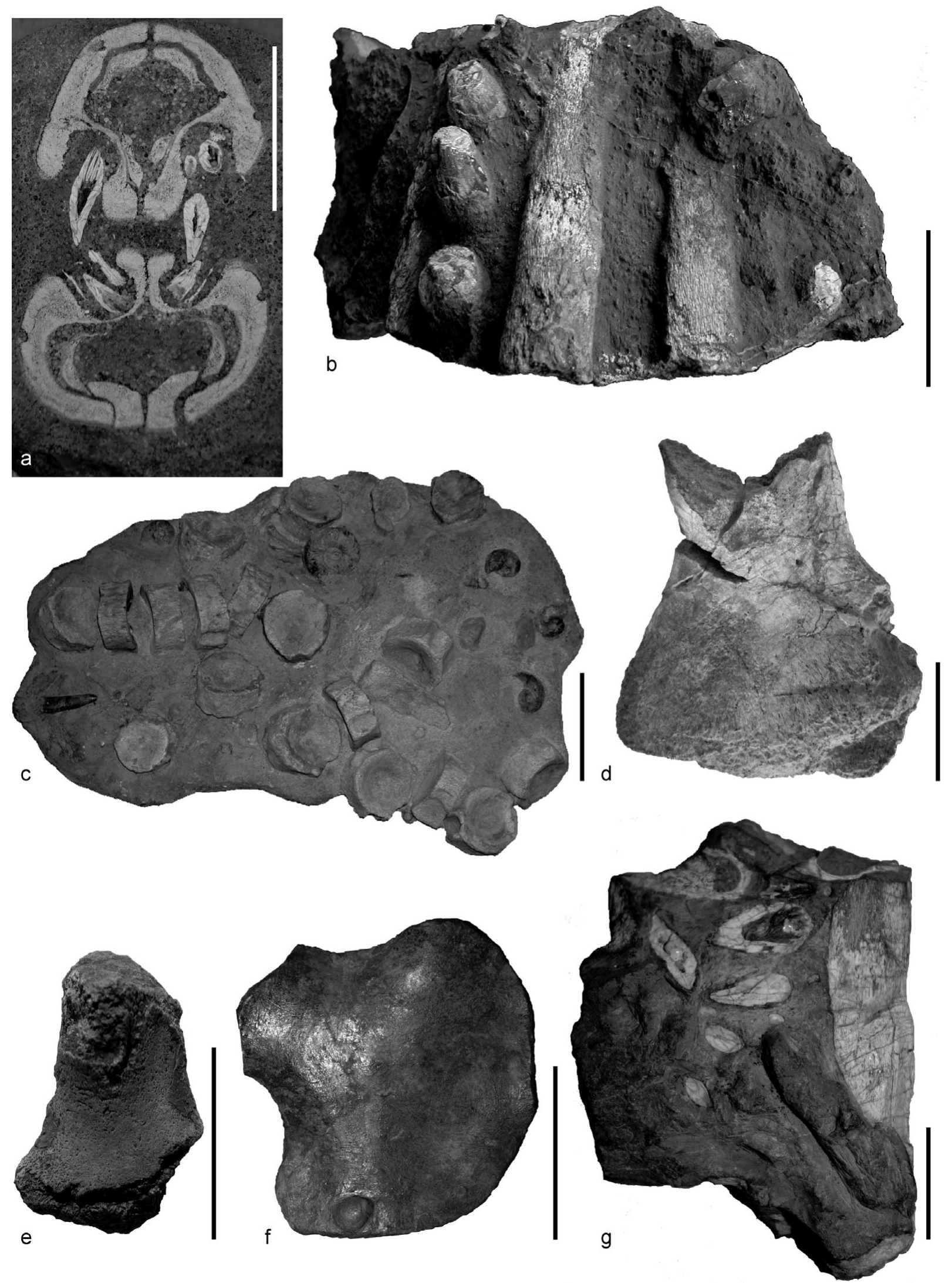

Figure 4. Ichthyosaurian remains from the Toarcian of Beaujolais, France. (a) Transverse section of a rostrum, Ichthyosauria indet. (PF Toa 467). (b) Cranial elements, Temnodontosaurus sp. (PF Toa 485). (c) Vertebrae, Thunnosauria indet. (PF Toa 514). (d) Humerus, non-thunnosaurian Neoichthyosauria indet. (MHNL 20103011). (e) Femur, Stenopterygiidae indet. (MHNL 20103016). (f) Coracoid, Ichthyosauria indet. (PF Aal 309). (g) Cranial elements, Ichthyosauria indet. (PF Aal 308). Scale bars represent: (a, b, d) $5 \mathrm{~cm}$; (c, f) $10 \mathrm{~cm} ;(\mathrm{e}, \mathrm{g}) 2.5 \mathrm{~cm}$. 
McGowan \& Motani, 2003; Ophthalmosauridae: Andrews, 1910; Zammit, Norris \& Kear, 2010; pers. obs.). Distally, there are two concave and oval articular facets. The anterior facet of the tibia appears to be slightly longer than that of the fibula. The surface of the femur is made of finished bone, which suggests maturity. The small size of the femur and its shape indicates that it belongs to Thunnosauria, a clade of derived ichthyosaurs with reduced hind limbs. As in some Stenopterygius specimens, and unlike Ichthyosaurus, the femur is short (proximal-distal distance) relative to its depth (dorsal-ventral distance) (McGowan \& Motani, 2003; Caine \& Benton, 2011). The femur also lacks the raised ridge in the distal part of the anterior surface seen in Ichthyosaurus (McGowan \& Motani, 2003; Maxwell, Zammit \& Druckenmiller, 2012). Accordingly, this specimen is tentatively referred to Stenopterygiidae indet.

$\mathrm{PF}$ Aal 309 is a coracoid of an indeterminate ichthyosaur (Fig. 4f). This fan-shaped element presents two lateral facets. The anterior one, for articulation with the scapula, is the longest. The posterior one represents the coracoidal contribution to the glenoid. The coracoid has a prominent emargination on its anterior edge, medial to the scapular facet and a second larger emargination on its lateral edge, posterior to the glenoid contribution. This specimen is referred to Ichthyosauria indet.

PF Aal 308 is a partial rostrum (Fig. 4g). The partially preserved dental grooves bear nine teeth. They are all very pointed and slender without constriction between the crown and the root. The root apparently had a somewhat rectangular, rather than rounded, crosssection and could indicate immaturity as in derived ichthyosaurs such as Ophthalmosaurus icenicus (VF, pers. obs. of GLAHM material). Nevertheless, tooth root cross-section is also known to vary with position along the jaw in other ophthalmosaurids (Kear, 2005) and therefore cannot be regarded as a robust indicator of osteological immaturity. This specimen is referred to Ichthyosauria indet.

\section{3.d. Plesiosauria}

Plesiosaur remains are rare in the Lafarge Quarry and occur in the Aalenian (PF Aal 186-187). Diagnostic elements include postcranial remains preserved in two incompletely prepared blocks of fine-grained, winecoloured sandstone (PF Aal 186-187; Fig. 5). These remains (Fig. 5a) correspond to sub-articulated postcranial elements of a single individual and preserve dorsal vertebrae, ribs and girdle fragments. The six preserved dorsal vertebrae present well-rounded centra (Fig. 5b). All centra are slightly wider than long and high (W > $\mathrm{L}>\mathrm{H}$ ). The dorsal groove for the neural canal gives a slightly heart-shape to each centrum. The dorsal centra bear slightly concave articular surfaces with rugose margins. The facets for the ribs are placed high up and entirely bear by the neural arch. The lateral surfaces beneath the neural arch are concave. The neural arches are strongly built and bear large pre- and postzygapophyses which are narrower than the centrum. The high neural spine is more than twice the height of the centrum, and blade-like, with a slightly convex apex. Several long and robustly recurved single-headed dorsal ribs are preserved. The bone girdle elements are flat and fragmentary, but their poor preparation and preservation preclude further determination.

\section{3.e. Crocodilians}

Crocodilian remains from the Lafarge Quarry occur in the Toarcian serpentinum zone (PF Toa 663; MHNL 20103014.2; MHNL 20103047), the bifrons zone (MHNL 20103015), and up into the upper Toarcian (PF Toa 468). Diagnostic elements include: two jaw fragments (PF Toa 663; Fig. 5c and MHNL 20103015; Fig. 5f), teeth (MHNL 20103014.2; Fig. 5d), one osteoderm (MHNL 20103047; Fig. 5e), vertebrae (PF Toa 470, MHNL 20103041; Figs. 5g-i), and a femur (PF Toa 468; Fig. 5j).

PF Toa 663 is a partial dentary preserving at least 14 alveoli with shallow cupular pits in between (Fig. 5c). The elongate and shallow bone bears circular and regularly spaced alveoli of similar size reminiscent of a non-diagnostic thalattosuchian.

The bone beds yielded several isolated crocodilian teeth (e.g. MHNL 20103014.2; Fig. 5d). They are relatively small, slender, curved and conical in shape. In addition to the mesiodistal carinae, they bear fine vertical ridges on their lingual and labial surfaces. Such piercing morphologies are seen in Steneosaurus, Platysuchus or Pelagosaurus and are typical of longirostrine marine crocodilians, so no further identification can be advanced.

MHNL 20103047 is an osteoderm showing several ovoid and large pits and is rectangular in shape (Fig. 5e). The presence of a prominent lateral keel is reminiscent of the double row of osteoderms of the dorsal armour of non-eusuchian mesoeucrocodylians (see reconstructions in Salisbury \& Frey, 2000). Among thalattosuchians, the presence of a dorsal keel may exclude an attribution to the genus Pelagosaurus (see specimens in Pierce and Benton, 2006; Lepage et al. 2008).

MHNL 20103015 is a piece of jaw presented in section and showing internal vacuities (Fig. 5f). The absence of the large narial duct and the presence of three pneumatic zones indicate that this jaw fragment represents the articulated dentaries. Its morphology is ovoid and dorsoventrally compressed, indicating a tubular snout. This trait, and the presence of three well-spaced alveoli, is reminiscent of longirostrine thalattosuchians.

PF Toa 470 and MHNL 20103041 are two isolated elongated, hourglass-shaped and mediolaterally compressed vertebral centra, interpreted as caudal centra. They lack a neural arch and spine (Figs $5 \mathrm{~g}-\mathrm{i}$ ). They are reminiscent of the mesoeucrocodylian condition in being amphicoelous (Salisbury \& Frey, 2000). 

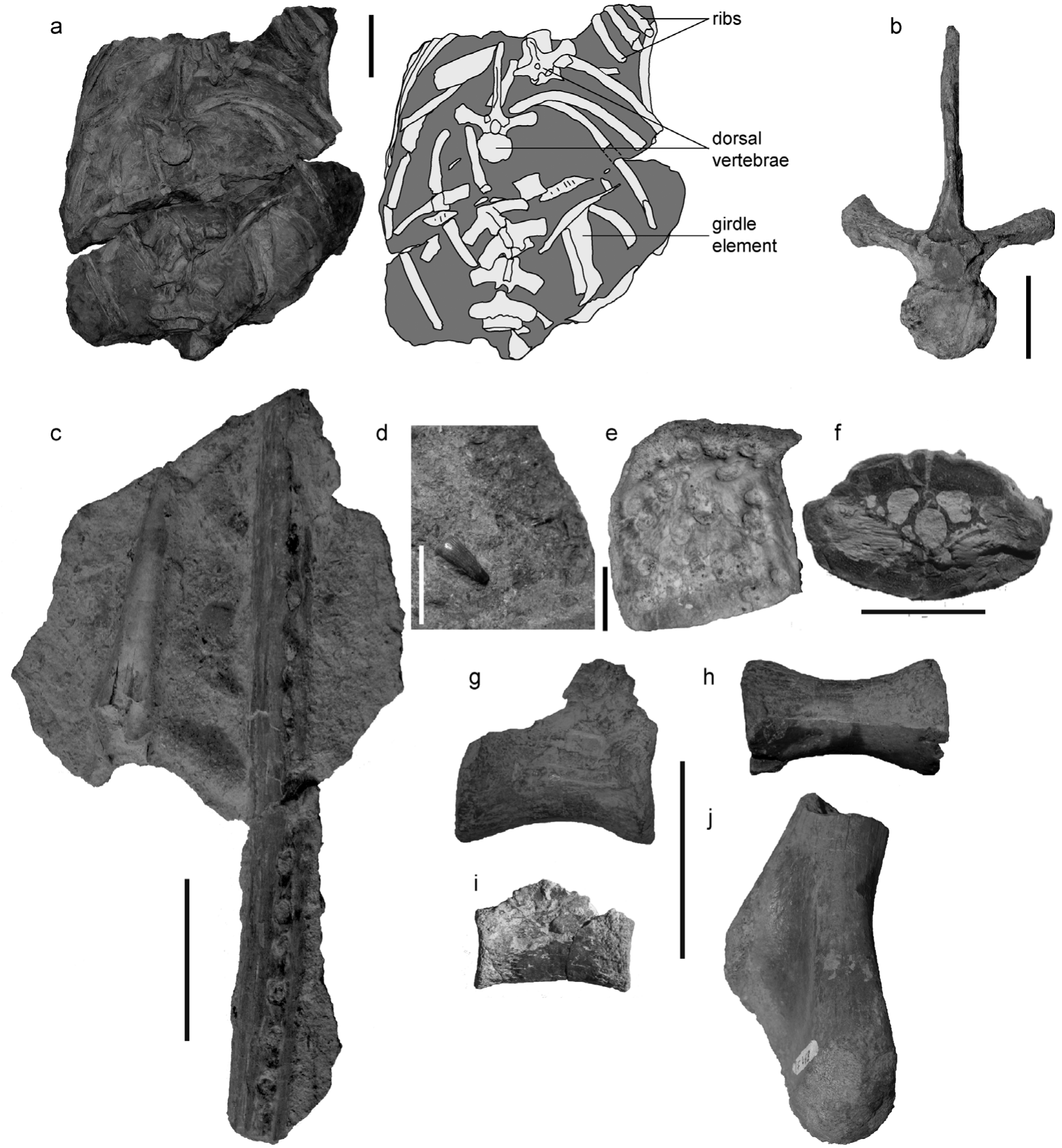

Figure 5. Plesiosaur and thalattosuchian crocodilian remains from the Toarcian and Aalenian of Beaujolais, France. (a) Photograph and line drawing, Plesiosauria indet. (PF Aal 186-187). (b) Dorsal vertebra (PF Aal 186-187). (c) Partial mandible, Thalattosuchia indet. (PF Toa 663). (d) Tooth, Crocodilia indet. (MHNL 20103014.2). (e) Osteoderm, Thalattosuchia indet. (MHNL 20103047). (f) Piece of jaw, Thalattosuchia indet. (MHNL 20103015). (g, h) Caudal vertebra, Thalattosuchia indet. (PF Toa 470) in (g) lateral and (h) ventral view; (i), caudal vertebra in lateral view, Thalattosuchia indet. (MHNL 20103041). (j) Partial distal part of a femur, Crocodilia indet. (PF Toa 468). Scale bars represent: (a) $10 \mathrm{~cm}$; (b, c, g, h, I, j) $5 \mathrm{~cm}$; (d, e, f) $1 \mathrm{~cm}$.

$\mathrm{PF}$ Toa 468 is a proximal portion of a right curved femur. It presents a well-rounded condyle and a well expressed fourth trochanter (Fig. $5 \mathrm{j}$ ).

\section{Discussion}

4.a. Stratigraphic range and implications for evolution of vertebrate diversity during the Early-Middle Jurassic

The Lafarge quarry site records an almost continuous Toarcian - lower Aalenian marine succession, which, in contrast to other Toarcian exposures, yields abundant vertebrate remains throughout (Fig. 2). Indeed, due to regional unconformities, most of the upper Toarcian is missing in Yorkshire and SW Germany (e.g. Cope et al. 1980; Riegraf, 1985), where vertebrate remains have been almost exclusively reported from the falciferum (SW Germany) and basal bifrons (Yorkshire) ammonite zones (Benton \& Taylor, 1984; Benton \& Spencer, 1995; F. Gro $\beta$ mann, unpub. Ph.D. thesis, Der Geowissenschaftlichen Fakultät der 
Eberhard-Karls-Universität Tübingen, 2006). The complete Toarcian succession at the study site, with only $12 \mathrm{~m}$ of strata, appears highly condensed when compared to most coeval exposures and boreholes where the Toarcian, when complete, generally exceeds $50 \mathrm{~m}$ (de Graciansky et al. 1998). Much reduced sedimentation rates, as suggested by the exceptionally high invertebrate abundance (Rulleau, 2006), are likely to explain the high abundance of vertebrate remains in the whole Toarcian succession of the Lafarge quarry site. These remains are mainly isolated bones or teeth of marine vertebrates: actinopterygians, neoselachians, ichthyosaurians, plesiosaurians and marine crocodilians. Most cannot be identified at the infra-familial level, but some are tentatively identified at the generic level.

Ichthyosaur fossils outnumber crocodilians and plesiosaurs throughout the Toarcian-Aalenian succession of the Beaujolais foothills. These apparent marine vertebrate abundances appear similar to those documented in other less complete Toarcian marine successions from NW Europe (Yorkshire: Benton \& Taylor, 1984; Benton \& Spencer, 1995; Holzmaden: F. Gro $\beta$ mann, unpub. Ph.D. Thesis, Der Geowissenschaftlichen Fakultät der Eberhard-Karls-Universität Tübingen, 2006) and Lower Jurassic strata of England (e.g. Benton \& Spencer, 1995; Smith \& Radley, 2007). One exception to these general trends is the dominance of crocodilians in Luxembourg, which might reflect the more proximal setting of this locality during the Early Jurassic period (P. Godefroit, unpub. Ph.D. thesis, Univ. catholique de Louvain, Faculté des Sciences, 1994). Although more specimens and finer stratigraphic resolution are needed to confirm these patterns in the southern Beaujolais, these observations suggest that no abrupt change in the relative composition of Jurassic marine reptile groups followed the Toarcian. Therefore, marine reptile assemblages appear relatively unaffected by the severe environmental changes (e.g. Hesselbo et al. 2007; Suan et al. 2010; Gómez \& Goy, 2011) characterizing this interval.

Another significant feature of the Lafarge quarry vertebrate fauna is the occurrence of possible remains of Temnodontosaurus in upper Toarcian strata. Specimens attributed to this genus have previously been reported in strata from the Hettangian angulata ammonite zone to the middle Toarcian bifrons ammonite zone (McGowan $\&$ Motani, 2003), but its relatives are absent in younger levels. If correct, the attribution of the specimen PF Toa 485 to Temnodontosaurus thus extends the stratigraphic range of this genus substantially and suggests that its extinction horizon might not be related to the T-OAE. Similarly, the presence of a possible stenopterygiid (MHNL 20103016) in the variabilis zone is also stratigraphically significant, since this clade mainly occurs in the strata of the tenuicostatum, falciferum and bifrons ammonite zones in Germany and the UK (Maisch, 2008; Caine \& Benton, 2011; Maxwell, 2012). Our new data, together with the recent description of two Aalenian Stenopterygius specimens (Maxwell, Fernández \& Schoch, 2012) provide additional evid- ence for the presence of the group after the T-OAE and suggest that its disappearance was also unrelated to the event.

In this context, the new material from the Aalenian is particularly significant in that it links the history of marine amniote groups through the Jurassic. Two groups have been recovered from the Aalenian stage of the Lafarge quarry, namely Plesiosauria and Ichthyosauria. Only scanty remains of plesiosaurs have been described from this stage in Germany and France (see Vincent, Bardet \& Morel, 2007 and references therein). The specimen PF Aal 186-187 is thus one of the few plesiosaur fossils found in Aalenian strata worldwide (Gasparini, 1992; Vincent, Bardet \& Morel, 2007; Kear, 2012) and the second most complete found in France (Vincent, Bardet \& Morel, 2007). Similarly, Aalenian ichthyosaur remains have only been found in southern France (Arnaud, Monleau \& Wenz, 1976) and Germany, where they are represented by one partial and one sub-complete specimen (Fernández, 1999; Maxwell, Fernández \& Schoch, 2012) and near the Aalenian-Bajocian boundary in Argentina (Fernández, 2003). These specimens thus represent one of the few Aalenian ichthyosaurs found and described worldwide. New marine crocodilian material (isolated vertebrae; currently under mechanical preparation) has been recently (2011) collected from the lower Aalenian of the Lafarge quarry site, and potentially represents the first significant record of the group in the Aalenian. In summary, the Aalenian vertebrate remains presented here, although essentially represented by fragmentary material, are especially significant in that they permit the inference of marine amniote abundance through a poorly documented interval.

\section{4.b. Palaeobiogeographic implications}

The Lafarge quarry site provides interesting clues about the palaeobiogeography of marine vertebrates during the Early-Middle Jurassic transition. Indeed, since southern European sites have yielded isolated marine amniote remains but no association of contemporaneous ichthyosaurs, plesiosaurs and crocodilians (Sander \& Bucher, 1993; Delfino \& Dal Sasso, 2006; Bardet, Pereda Suberiola \& Ruiz-Omeñca, 2008b; Fischer, Guiomar \& Godefroit, 2011; Smith, Araújo \& Mateus, 2012), the Lafarge quarry succession preserves the southernmost vertebrate assemblage of this age. The occurrence of remains assignable to probable Temnodontosaurus and stenopterygiid at the study site indicates a broad similarity with German and English sites. In addition, the actinopterygian assemblage, formed by Leptolepis sp. and Dapedium or Lepidotes-like remains, is reminiscent of that from other well-known Lower Jurassic European localities, in France (La Caine, Sainte Colombe, see Wenz, 1967), Germany (Holzmaden), England (Lyme Regis, Whitby) and Belgium (Fontenoille, see Delsate, Duffin \& Weiss, 2002). Chondrichthyians, represented by hybodontiforms and one neoselachian, similarly suggest a widespread distribution. These similarities reinforce 
the idea that these free-swimming animals had rather a cosmopolitan distribution in European epicontinental seas near the early-middle Toarcian transition, consistent with coeval ammonite assemblages (Dera et al. 2011). However, this faunal homogeneity contrasts with the relatively strong palaeobiogeographic zonation suggested for certain groups of marine reptiles in Europe during the Toarcian (e.g. Maisch \& Ansorge, 2004). The presence of different taxa at the various sites could be related to palaeolatitudinal temperature gradients, but is more likely correspond to discovery biases considering the relatively few documented specimens and the ammonite-zone-level diachronism of the marine reptile-yielding sites (Smith \& Vincent, 2010; Benson, Ketchum \& Noé, 2011). In this context, ongoing investigations of the almost complete and fossiliferous Toarcian-Aalenian succession in southern France will undoubtedly provide further valuable bases for reconstructing the palaeobiogeographical distribution of vertebrates among European epicontinental seas.

\section{Conclusion}

The completeness and temporal extension of the Lafarge quarry succession extends the stratigraphical range of the ichthyosaur genus Temnodontosaurus to the upper Toarcian and suggests the presence of stenopterygiids in the uppermost middle Toarcian. The reported occurrences of these successful taxa, combined with their apparent absence in Middle Jurassic strata, suggests that their disappearance occurred after the Toarcian and was unrelated to the T-OAE. Given the very seldom occurrence of marine vertebrates reported from the Middle Jurassic, it is difficult to determine whether the extinction of those taxa, diversified and abundant during the Early Jurassic, was gradual or rapid and potentially the result of severe environmental perturbations. Similarly, pre TOAE specimens (i.e. from the upper Pliensbachian and lowermost Toarcian) are relatively scarce, hence preventing detailed reconstruction of extinction and diversification dynamics of marine vertebrates over this interval. In this context, the almost continuous record of vertebrate specimens from the biostratigraphically well-constrained marine succession described above, opens an interesting avenue of research for further highresolution tracing of the evolution of vertebrate fauna across this key interval.

Acknowledgements. We acknowledge the generous logistical support of Lafarge and the financial support from the Musée des Confluences de Lyon. We also warmly thank all the volunteers who provided crucial help and entertainment during the fieldwork campaigns of 2009 and 2010 (J. Banse, J. Castera, J. Milad, V. Perrier, J. Planck, T. Rigaudier, A. Richard, E. Sarroca, J. Schlögl, members of the GéoPaléo section). B. Kear is thanked for his helpful and constructive reviews that helped to improve the quality of the manuscript. Thanks to Sally Thomas for her very efficient assistance with proof and copy editing. This work was supported by the Alexander von Humboldt Foundation (PV), a Marie-Curie Postdoctoral Fellowship, FP7-PEOPLE-2010-IEF (J.E.M), a
FNRS grant (VF; aspirant du F.R.S.-FNRS) and a CNPQ grant (BK).

\section{References}

AGASSIZ, L. 1833-1844. Recherches sur les poissons fossiles. Petitpierre, Neuchâtel. 1420 pp.

ANDREWS, C. W. 1910. A Descriptive Catalogue of the Marine Reptiles of the Oxford Clay, Part I. London: British Museum of Natural History, 205 pp.

Arnaud, M., Monleau, C. \& WenZ, S. 1976. Découverte de restes d'ichthyosaures dans l'Aalénien du Massif de la Loube (Var). Bulletin du Muséum d'Histoire Naturelle de Marseille 36,17-18.

BARDET, N. 1994. Extinction events among Mesozoic marine reptiles. Historical Biology 7, 313-24.

BARdet, N., Fernández, M., Garcia-Ramos, J. C., Pereda Suberbiola,X., Pinuela,L., Ruiz-OMeñaCA, J. I. \& VinCENT, P. 2008a. A juvenile plesiosaur from the Pliensbachian (Lower Jurassic) of Asturias, Spain. Journal of Vertebrate Paleontology 28, 258-63.

Bardet, N., Pereda Suberbiola, X. \& Ruiz-Omeñaca, J. I. 2008b. Mesozoic marine reptiles from the Iberian Peninsula. Geo-Temas 10, 1245-48.

Baudin, F., Herbin, J.-P. \& VAndenbroucke, M. 1990. Mapping and geochemical characterization of Toarcian organic matter in the Mediterranean Tethys. Organic Geochemistry 16, 677-87.

Benson, R. B. J., Butler, R. J., Lindgren, J. \& Smith, A. S. 2010. Mesozoic marine tetrapod diversity: mass extinctions and temporal heterogeneity in geological megabiases affecting vertebrates. Proceedings of the Royal Society B: Biological Sciences 277, 829-34.

Benson, R. B., Ketchum, H. F. \& NoÉ, L. F. 2011. New information on Hauffiosaurus (Reptilia, Plesiosauria) based on a new species from the Alum Shale Member (Lower Toarcian: Lower Jurassic) of Yorkshire, UK. Palaeontology 54, 547-71.

Benson, R. B. J., Evans, M. \& DRUCKENMILleR, P. S. 2012. High diversity, low disparity and small body size in plesiosaurs (Reptilia, Sauropterygia) from the TriassicJurassic boundary. PLOS ONE 7: e31838.

Benton, M. J. 1990a. Mass extinctions in the fossil record of late Palaeozoic and Mesozoic tetrapods. In Extinction Events in Earth History (eds E. G. Kauffman \& O. H. Walliser), pp. 239-51. Springer, Lecture Notes in the Earth Sciences vol. 30, 432 pp.

Benton, M. J. 1990b. Reptiles. In Evolutionary Trends (ed. K. McNamara), pp. 279-300. London: Belhaven, 368 pp.

Benton, M. J. 1993. Reptiles. In The Fossil Record 2 (ed. M. J. Benton), pp. 681-715. London: Chapman and Hall.

Benton, M. J. \& Spencer, P. S. 1995. Fossil reptiles of Great Britain. Geological Conservation Review Series, vol. 10, series 4. London: Chapman and Hall, London, $386 \mathrm{pp}$.

Benton, M. J. \& TAYloR, M. A. 1984. Marine reptiles from the Upper Lias (Lower Toarcian, Early Jurassic) of the Yorkshire coast. Proceedings of the Yorkshire Geological Society 44, 399-429.

CAine, H. \& Benton, M. J. 2011. Ichthyosauria from the Upper Lias of Strawberry Bank, England. Palaeontology 54, 1069-93.

Caswell, B. A., Coe, A. L. \& Cohen, A. S. 2009. New range data for marine invertebrate species across the early Toarcian (Early Jurassic) mass extinction. Journal of the Geological Society, London 166, 859-72. 
Cope, J. C. W., GetTy, T. A., Howarth, M., Morton, N. \& TORRENS, H.S. 1980. A Correlation of Jurassic Rocks in the British Isles. Part One: Introduction and Lower Jurassic. Geological Society of London Special Report, no. 14,73 pp.

De Graciansky, P.-C., Dardeau, G., Dommergues, J. L., Durlet, C., MARChAND, D., DumONT, T., HesSElbo, S. P., JACQuin, T., Goggin, V., MeIster, C., Mouterde, R., REY, J. \& VAIL, P. R. 1998. Ammonite biostratigraphic correlation and Early Jurassic sequence stratigraphy in France: comparisons with some U.K. sections. In Mesozoic and Cenozoic Sequence Stratigraphy of European Basins (eds P.-C. De Graciansky, T. Jacquin, X. Farley \& P.R. Vail), pp. 583-622. SEPM Special Publication no. 60.

Delfino, M. \& DAl SASSO, C. 2006. Marine reptiles (Thalattosuchia) from the Early Jurassic of Lombardy (northern Italy). Geobios 39, 346-54.

Delsate, D., Duffin, C. J. \& Weiss, R. 2002. A new microvertebrate fauna from the Middle Hettangian (Early Jurassic). Memoirs of the Geological Survey of Belgium 16, 1-84.

Dera, G., Neige, P., Dommergues, J.-L. \& Brayard, A. 2011. Ammonite paleobiogeography during the Pliensbachian-Toarcian crisis (Early Jurassic) reflecting paleoclimate, eustasy, and extinctions. Global and Planetary Change 78, 92-105.

Elmi, S. \& RulleaU, L. 1991. Le Toarcien des carrières Lafarge (Bas-Beaujolais, France): cadre biostratigraphique de référence pour la région lyonnaise. Geobios $\mathbf{2 4}$, 315-31.

Elmi, S. \& RUlleaU, L. 1993. Le Jurassique du Beaujolais méridional. Geobios 15, 139-55.

FERNÁNDEZ, M. 1999. A new ichthyosaur from the Los Molles Formation (Early Bajocian, Neuquén Basin, Argentina). Journal of Paleontology 73, 677-81.

FERNÁNDEZ, M. 2003. Ophthalmosauria (Ichthyosauria) forefin from the Aalenian-Bajocian boundary of Mendoza Province, Argentina. Journal of Vertebrate Paleontology 23, 691-4.

Fischer, V., Guiomar, M. \& Godefroit, P. 2011. New data on the palaeobiogeography of Early Jurassic marine reptiles: the Toarcian ichthyosaur fauna of the Vocontian Basin (SE France). Neues Jarhbuch für Geologie und Paläontologie 261, 111-27.

GASPARINI, Z. 1992. Marine reptiles of the Circum-Pacific region. In The Jurassic of the Circum-Pacific (ed. G.E.G. Westermann), pp. 361-4. Cambridge University Press, Series World and Regional Geology no. 3.

GODEFROIT, P. 1993. Les grands ichthyosaures sinémuriens d'Arlon. Bulletin de l'Institut Royal des Sciences Naturelles de Belgique Sciences de la Terre 63, 25-71.

GODEFROIT, P. 1996. Un crâne d'Ichthyosaurus communis (Reptilia, Ichthyosauria) du Sinémurien supérieur de Lorraine belge. Bulletin de la Société belge de Géologie 104, 77-89.

GómEZ, J. J. \& GoY, A. 2011. Warming-driven mass extinction in the Early Toarcian (Early Jurassic) of northern and central Spain. Correlation with other time-equivalent European sections. Palaeogeography, Palaeoclimatology, Palaeoecology 306, 176-95.

GroßmanN, F. 2007. The taxonomic and phylogenetic position of the Plesiosauroidea from the Lower Jurassic Posidonia Shale of south-west Germany. Palaeontology 50, 545-64.

HARries, P. J. \& LitTle, C. T. S. 1999. The early Toarcian (Early Jurassic) and the Cenomanian-Turonian (Late Cretaceous) mass extinctions: similarities and contrasts.
Palaeogeography, Palaeoclimatology, Palaeoecology 154, 39-66.

Hesselbo, S. P., Jenkyns, H. C., Duarte, L.V. \& OLIVEIRA, L. C. V. 2007. Carbon-isotope record of the Early Jurassic (Toarcian) Oceanic Anoxic Event from fossil wood and marine carbonate (Lusitanian Basin, Portugal). Earth and Planetary Science Letters 253, 455-70.

JENKYNS, H. C. 1988. The early Toarcian (Jurassic) event: stratigraphy, sedimentary, and geochemical evidence. American Journal of Science 288, 101-51.

KEAR, B. P. 2005. Cranial morphology of Platypterygius longmani Wade, 1990 (Reptilia: Ichthyosauria) from the Lower Cretaceous of Australia. Zoological Journal of the Linnean Society 145, 583-622.

KEAR, B. P. 2012. A revision of Australia's Jurassic plesiosaurs. Palaeontology 55, 1125-38.

Lepage, Y., Buffetaut, E., Hua, S., Martin, J. E. \& TABOUELLE, J. 2008. Catalogue descriptif, anatomique, géologique et historique des fossiles présentés à l'exposition 'Les crocodiliens fossiles de Normandie' (6 novembre - 14 décembre 2008). Bulletin de la Société Géologique de Normandie et des Amis du Muséum du Havre 95, 5-152.

LitTLE, C. T. S. \& Benton, M. J. 1995. Early Jurassic mass extinction: a global long-term event. Geology 23, 49598.

MACCHIONI, F. \& CECCA, F. 2002. Biodiversity and biogeography of middle-late Liassic ammonoids: implications for the Early Toarcian mass extinction. Geobios Mémoire spécial 24, 166-75.

MAISCH, M.W. 2001. Neue Exemplare der seltenen Ichthyosauriergattung Suevoleviathan Maisch 1998 aus dem Unteren Jura von Südwestdeutschland. Geologica et Palaeontologica 35, 145-60.

MAISCH, M. W. 2008. Revision der Gattung Stenopterygius Jaekel, 1904 emend. von Huene, 1922 (Reptilia: Ichthyosauria) aus dem unteren Jura Westeuropas. Palaeodiversity 1, 227-71.

Maisch, M. W. \& Ansorge, J. 2004. The Liassic ichthyosaur Stenopterygius cf. quadriscissus from the lower Toarcian of Dobbertin (northern Germany) and some considerations on lower Toarcian marine reptile paleobiogeography. Paläontologische Zeitschrift $\mathbf{7 8}$, 161-71.

MAISEY, J. 1978. Growth and form of finspines in hybodont sharks. Palaeontology, 21, 657-66.

MARTin, J. E., Fischer, V., VINCENT, P. \& SUAN, G. 2012. A longirostrine Temnodontosaurus (Ichthyosauria) with comments on Early Jurassic ichthyosaur niche partitioning and disparity. Palaeontology 55, 995-1005.

MAXWELL, E. E. 2012. New metrics to differentiate species of Stenopterygius (Reptilia: Ichthyosauria) from the Lower Jurassic of southwestern Germany. Journal of Paleontology 86, 105-15.

Maxwell, E. E., Fernández, M. S. \& SCHOCH, R. R. 2012. First diagnostic marine reptile remains from the Aalenian (Middle Jurassic): a new ichthyosaur from southwestern Germany. PLoS ONE 7, e41692.

MaXwell, E. E, ZAMmit, M. \& DRUCKenMiller, P. S. 2012. Morphology and orientation of the ichthyosaurian femur. Journal of Vertebrate Paleontology 32, 1207 11.

MCGOWAN, C. 1996. Giant ichthyosaurs of the Early Jurassic. Canadian Journal of Earth Sciences 33, 1011-21.

McGowan, C. \& Motani, R. 2003. Part 8 Ichthyopterygia. In Handbook of Paleoherpetology (ed. H.-D. Sues). München: Verlag Dr. Friedrich Pfeil, 175 pp. 
NyBELIN, O. 1962. Preliminary note on two species previously named Leptolepis bronni Agassiz. Arkiv för Zoologi, Serie 2 18, 303-6.

Nybelin, O. 1974. A Revision of Leptolepid Fishes. Acta Regiae Societatis Scientiarum et Litterarum Gothoburgensis. Zoologica 9, 202 pp.

Pierce, S. \& Benton, M. J. 2006. Pelagosaurus typus Bronn, 1841 (Mesoeucrocodylia: Thalattosuchia) from the Upper Lias (Toarcian, Lower Jurassic) of Somerset, England. Journal of Vertebrate Paleontology 26, 62135.

REES, J. 2008. Interrelationships of Mesozoic hybodont sharks as indicated by dental morphology - preliminary results. Acta geologica polonica 58, 217-21.

RIEGRAF, W. 1985. Mikrofauna, Biostratigraphie und Fazies im Unteren Toarcium Südwestdeutchlands und Vergleiche mit benachbarten Gebieten. Tübinger Mikropaläontologische Mitteilungen 3, 1-232.

RULlEAU, L. 1997. Nouvelles observations sur le Toarcien inférieur de la Région lyonnaise. Géologie de la France, 2, 13-22.

RULLEAU, L. 2006. Biostratigraphie et paléontologie du Lias supérieur et du Dogger de la région Lyonnaise (eds L. Rulleau \& la Section Géologie et Paléontologie du Comité d'Entreprise Lafarge Ciments). Dedale Editions, $381 \mathrm{pp}$

SAlisburY, S. \& FREY, E. 2000. A biomechanical transformation model for the evolution of semi-spheroidal articulations between adjoining vertebral bodies in crocodilians. In Crocodilian Biology and Evolution (eds G. C. Grigg, F. Seebacher \& C. E. Franklin), 85-134. Chipping Norton: Surrey Beatty \& Sons.

SANDER, P. M. 2000. Ichthyosauria: their diversity, distribution, and phylogeny. Paläontologische Zeitschrift 74, $1-35$.

SANDER, P. M. \& BUCHER, H. 1993. An ichthyosaur from the uppermost Toarcian of southern France. Neues Jahrbuch für Geologie und Paläontologie, Monatshefte 1993, 631-40.

SMith, A. S. \& RadLey, J. D. 2007. A marine reptile fauna from the Early Jurassic Saltford Shale (Blue Lias Formation) of central England. Proceedings of the Yorkshire Geological Society 56, 253-60.

SMITH, A. S. \& VincENT, P. 2010. A new genus of pliosaur (Reptilia: Sauropterygia) from the Lower Jurassic of Holzmaden, Germany. Palaeontology 53, 1049-63.

Smith, A. S., ARAúJo, R. \& MAteus, O. 2012. Lusonectes sauvagei, a new plesiosauroid from the Toarcian (Lower Jurassic) of Alhadas, Portugal. Acta Palaeontologica Polonica 57, 257-66.

Suan, G., Mattioli, E., Pittet, B., Mailliot, S. \& LÉCUYER, C. 2008. Evidence for major environmental perturbation prior to and during the Toarcian (Early Jurassic) oceanic anoxic event from the Lusitanian Basin, Portugal. Paleoceanography 23, PA1202.

Suan, G., Mattioli, E., Pittet, B., Lécuyer, C., Suchéras-Marx, B., Duarte, L.V., PhilipPe, M., REgGiani, L. \& MARTINEAU, F. 2010. Secular environmental precursors to Early Toarcian (Jurassic) extreme climate changes. Earth and Planetary Science Letters 290, 448-58.

THIES, D. 1991. The osteology of the bony fish Tetragonolepis semicincta BRONN 1830 (Actinopterygii, $\dagger$ Semionotiformes) from the Early Jurassic (Lower Toarcian) of Germany. Geologica et Palaeontologica 25, 251-97.

Thorne, P. M., RutA, M. \& Benton, M. J. 2011. Resetting the evolution of marine reptiles at the Triassic-Jurassic boundary. Proceedings of the National Academy of Sciences 108, 8339-44.

URLICHS, M., WILD, R. \& ZIEGLER, B. 1994. Der PosidonienSchiefer des unteren Juras und seine Fossilien. Stuttgarter Beiträge zur Naturkunde, Serie C 36, 1-95.

VINCENT, P. 2011. A re-examination of Hauffiosaurus zanoni, a pliosauroid from the Toarcian (Early Jurassic) of Germany. Journal of Vertebrate Paleontology 31, 340-51.

Vincent, P., BARdet, N. \& Morel, N. 2007. An elasmosaurid plesiosaur from the Aalenian (Middle Jurassic) of Western France. Neues Jahrbuch für Geologie und Paläontologie, Abhandlungen 243, 363-70.

VINCENT, P. \& SMith, A. S. 2009. A redescription of Plesiosaurus propinquus Tate \& Blake, 1876 (Reptilia, Plesiosauria), from the Lower Jurassic (Toarcian) of Yorkshire, England. Proceedings of the Yorkshire Geological Society 57, 151-60.

VULLO, R. 2011. Direct evidence of hybodont shark predation on Late Jurassic ammonites. Naturwissenschaften 98, 545-49.

Wenz, S. 1967. Compléments à l'étude des Poissons Actinoptérygiens du Jurassique français. Cahiers de Paléontologie, Editions du CNRS, 276 pp.

WestPHAL, F. 1962. Die Krokodilier des deutschen und englischen oberen Lias. Palaeontographica A 118, 23118.

Wignall, P. B., Newton, R. J. \& Little, C. T. S. 2005. The timing of paleoenvironmental change and causeand-effect relationships during the Early Jurassic mass extinction in Europe. American Journal of Science 305, 1014-32.

ZAmmit, M., Norris, R. M. \& KeAR, B. P. 2010. The Australian Cretaceous ichthyosaur Platypterygius australis: a description and review of postcranial remains. Journal of Vertebrate Paleontology 30, 1726-35. 